\title{
Analysis of clinical drug trials in children compared to clinical drug trials in adults, in Argentina
}

\author{
Laura Traversi, M.D. ${ }^{a}$ and Ricardo Bolaños, M.D. ${ }^{b}$
}

\begin{abstract}
Introduction. It is necessary to know the extent and subject matter of pediatric clinical drug research in Argentina and establish the differences with the adult population.

Objectives. To compare adult and pediatric clinical drug trials in terms of number, phase, design (placebo as control, proportion of blind/ open-label trials), studied diseases. Specifically in pediatrics, to determine if studied diseases are consistent with the leading causes of infant and child mortality in Argentina.

Methods. Analytical, observational, crosssectional study conducted at the National Drug, Food and Technology Administration of Argentina (Administración Nacional de Medicamentos, Alimentos y Tecnología Médica, ANMAT) in trials approved between 2011 and 2014.

Results. Out of 614 trials, $552(90 \%)$ were done in adults and $62(10 \%)$, in children. Phase III studies predominated in both adults $(77 \%)$ and children $(69 \%)$. In relation to study design, placebo control (49\%) and blinding (74\%) were more common in adults compared to children ( $31 \%$ and $58 \%$, respectively). The most frequently studied diseases were tumors in adults and respiratory, musculoskeletal and connective tissue diseases in children. No correlation was observed between studied diseases and infant and child mortality. Conclusions. 1) More studies were done in adults than in children; 2) most studies corresponded to phase III; 3) differences in study design were observed between children and adults; 4 ) studied diseases were different in each population; 5) in pediatrics, no correlation was observed between the studied diseases and the leading causes of infant and child mortality in Argentina.

Key words: clinical trials, pediatrics, clinical pharmacology.
\end{abstract}

http: / / dx.doi.org/10.5546/ aap.2019.eng.34

To cite: Traversi L, Bolaños R. Analysis of clinical drug trials in children compared to clinical drug trials in adults, in Argentina. Arch Argent Pediatr 2019;117(1):34-40.

\section{INTRODUCTION}

Clinical drug investigation in children has its specific characteristics, which is a true challenge for the participants involved in human research. In spite of this, it is necessary to study the use of drugs in this population because: 1 ) it has its own pathophysiological characteristics, understood as the occurrence of anatomical, physiological, and biochemical changes that affect the pharmacokinetics and pharmacodynamics of drugs from birth to adulthood; these sometimes result in different drug responses in relation to their effectiveness and safety; ${ }^{1}$ 2) the existence of diseases exclusive of childhood; 3 ) the presence of diseases with a different presentation and course; 4) the need for adequate drug formulations that optimize treatment adherence and that adjust active drug dosage strengths for administration.

High-quality drug clinical research in children entails a fundamental improvement for the pediatric public health in relation to treatments administered to children because, in clinical practice, drugs are frequently used off-label, i.e., for an unapproved indication.

Based on this need, in the past two decades, reference regulatory agencies, such as the United States Food and Drug Administration (FDA), have modified their regulations to promote drug research in pediatrics. They now require the performance of drug research in all age groups, the implementation of pediatric research programs, the development of pediatric formulation adjustments, and the inclusion of information from pediatric studies in the package insert. 
In Argentina, in 2010, the National Drug, Food and Technology Administration of Argentina (Administración Nacional de Medicamentos, Alimentos y Tecnología Médica, ANMAT) published Provision $6677,{ }^{2}$ which outlines the good clinical practice guidelines for drug trials in humans. This regulation provides an adequate framework to protect the interests of research participants and takes into account vulnerable populations, which include pediatric patients, and this is an advance from the previous provision (ANMAT Provision 5330/97) that has now been repealed. Regulatory actions, which favor pediatric research, are a critical advance towards remedying the prescriptive problem that exists in childhood today.

This study aims at paving a descriptiveguiding path that analyzes the extent and subject matter of drug research in children in Argentina and at establishing certain differences with the adult population. Knowing this information allows to prevent protocol duplications and to promote studies of interest to address research efforts in the direction of our pediatric population's therapeutic needs.

General objectives. To compare clinical drug research in children and adults in terms of number, phases, design aspects, such as the use of a placebo as control, and the proportion of blind/ open-label trials, and studied diseases.

Exploratory objectives. Specifically in pediatrics, to determine if studied diseases are consistent with the leading causes of infant and child mortality in Argentina.

\section{POPULATION AND METHODS}

Analytical, observational, cross-sectional study conducted at the ANMAT. Data were collected from a public database available at http: / / www. anmat.gov.ar/aplicaciones_net/applications / consultas/ensayos_clinicos/principal.asp. All clinical drug trials approved by the ANMAT between January $1^{\text {st }}, 2011$ and December $31^{\text {st }}$, 2014 were included. Trials that were out of the scope of application and coverage of Provision $6677 / 10$, unauthorized studies, bioavailability / bioequivalence studies, and studies conducted in both children and adults were excluded.

The methodology consisted in reviewing each protocol included in the public database that had been approved between 2011 and 2014, and to stratify them in two groups: a) studies done exclusively in individuals younger than 18 years and b) studies done in adults (18 years and older).
Data were introduced in a database; trials that did not meet selection criteria were excluded, and the number that complied with the study objectives was estimated. If information was incomplete, the original source was consulted, which was also available.

Trials were stratified by clinical phase into phase I (phase Ia and Ib), phase II (phase IIa and IIb), phase III (phase IIIa and IIIb), and other phases (I/II, Ib/II, II/ III, IIlb/III).

Diseases were categorized according to the International Classification of Diseases, Tenth Revision (ICD-10) of the World Health Organization (WHO). ${ }^{3}$

To comply with exploratory objectives, infant and child mortality rates were obtained from the data published by the National Ministry of Health in 2015. ${ }^{4}$

Hypothesis. The following differences are observed in drug trials conducted in children and adults in Argentina: The number of pediatric studies is smaller than that of adult studies. The number and proportion of phase I studies are smaller in children compared to adults. Design: A higher association was observed between adult age range and placebo use; the number and proportion of blind studies are smaller in children than in adults. Diseases: The most commonly studied diseases are different between children and adults.

Statistics. The total number of trials that met the inclusion/exclusion criteria was analyzed; it was not necessary to estimate the sample size.

Descriptive and inferential methods were used. The proportions were estimated and described as percentages and $95 \%$ confidence interval $(\mathrm{CI})$ as a measure of dispersion.

Inferential methods included the binomial test to compare proportions and the $\chi^{2}$ test to determine an association. A type I error $=5 \%$ (0.05) was established; and a $p$ value $<\alpha(5 \%)$ was accepted to reject the null hypothesis (H0). The BioEstat $5.3^{5}$ software was used.

Ethical aspects. Publicly available information was used and it was not possible to identify confidential data, so no ethical conflicts arose. This study did not require a submission before an Ethics Committee.

\section{RESULTS}

\section{Trials approved between 2011 and 2014}

The total number of studies that met the inclusion/exclusion criteria corresponded to $614,552(90 \%)$ adult trials and $62(10 \%)$ pediatric 


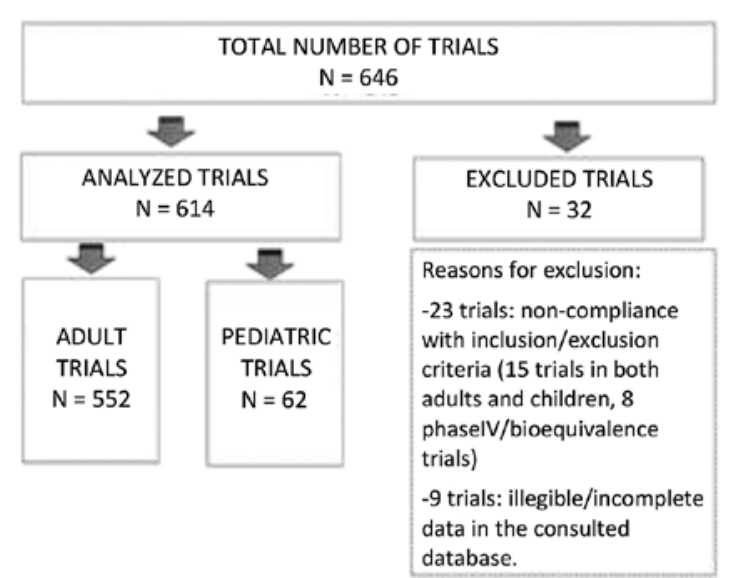

trials; a statistically significant difference $(p<0.0001)$ was observed (Table 1$)$.

The analysis of annual pediatric trials showed an upward trend: the number of trials doubled in 2014 compared to 2011 (Table 2).

\section{Phases:}

The most commonly studied phase in Argentina corresponded to phase III, both in adults $(77 \%)$ and children $(69 \%)$. In relation to phase I, it accounted for $2 \%$ and $5 \%$ of studies in adults and children, respectively, without statistically significant differences $(p=0.2)$ between both populations (Table 3).

Design aspects

Use of placebo. Placebo was used in $49 \%$ of adult trials and in $31 \%$ of pediatric trials; a greater association was observed between the adult age range and placebo use $(p=0.0074)$ (Table 4$)$.

Blinding. Both adult and pediatric trials most frequently included blinding (double/ single blind), but it was more common in adults $(74 \%)$ than in children (58\%), and a statistically significant difference was observed $(p=0.0224)$.

\section{Diseases}

Adults. The most commonly studied disease were tumors $(24 \%)$, followed by musculoskeletal

TABLE 1. Total number of phase I/II/III clinical drug trials approved by ANMAT* between 2011 and 2014

\begin{tabular}{lcccc}
\hline Age range & & Approved trials (2011-2014) & CI (\%) \\
\hline Adults & $\mathbf{N}$ & $\%$ & $(87.5-92.3)$ \\
Children & 552 & 90 & $(7.7-12.5)$ \\
Total & 62 & 10 & - \\
\hline
\end{tabular}

* National Drug, Food and Technology Administration of Argentina.

Data between parentheses correspond to $95 \%$ confidence interval limits.

TABLE 2. Phase I/II/III clinical trials approved by the ANMAT* per year between 2011 and 2014

\begin{tabular}{lcccccccc} 
Age range & \multicolumn{2}{c}{$\mathbf{2 0 1 1}$} & \multicolumn{2}{c}{$\mathbf{2 0 1 2}$} & \multicolumn{2}{c}{$\mathbf{2 0 1 3}$} & \multicolumn{2}{c}{$\mathbf{2 0 1 4}$} \\
\hline & $\mathbf{N}$ & $\%(\mathbf{C I})$ & $\mathbf{N}$ & $\% \mathbf{( C I )}$ & $\mathbf{N}$ & $\%(\mathbf{C I})$ & $\mathbf{N}$ & $\%(\mathbf{C I})$ \\
\hline Adults & 141 & $94 \%(90.2-97.8)$ & 112 & $88 \%(82.6-93.8)$ & 169 & $89 \%(85-93.8)$ & 130 & $88 \%(82.6-93.1)$ \\
Children & 9 & $6 \%(2.2-9.8)$ & 15 & $12 \%(6.2-17.4)$ & 20 & $11 \%(6.2-15)$ & 18 & $12 \%(6.9-17.4)$ \\
Total & 150 & $100 \%$ & 127 & $100 \%$ & 189 & $100 \%$ & 148 & $100 \%$ \\
\hline
\end{tabular}

* National Drug, Food and Technology Administration of Argentina.

Data between parentheses correspond to $95 \%$ confidence interval limits.

TABLE 3. Phases of clinical trials approved by the ANMAT* between 2011 and 2014

\begin{tabular}{|c|c|c|c|c|c|c|c|c|c|}
\hline \multirow[t]{2}{*}{ Age range } & \multicolumn{2}{|c|}{ Phase I } & \multicolumn{2}{|c|}{ Phase II } & \multicolumn{2}{|c|}{ Phase III } & \multicolumn{2}{|c|}{ Other phases } & \multirow{2}{*}{$\begin{array}{c}\text { Total number } \\
\text { of studies }\end{array}$} \\
\hline & $\mathbf{N}$ & $\%(\mathrm{CI})$ & $\mathbf{N}$ & $\%(\mathrm{CI})$ & $\mathbf{N}$ & $\%(\mathrm{CI})$ & $\mathbf{N}$ & $\%(\mathrm{CI})$ & \\
\hline Adults & 8 & $2 \%(0.5-2.4)$ & 113 & $20 \%(17.1-23.8)$ & 425 & $77 \%(73.5-80.5)$ & 6 & $1 \%(0.2-2.0)$ & $552(100 \%)$ \\
\hline Children & 3 & $5 \%(-)$ & 15 & $24 \%(13.5-34.9)$ & 43 & $69 \%(57.9-80.8)$ & 1 & $2 \%(-)$ & $62(100 \%)$ \\
\hline
\end{tabular}

* National Drug, Food and Technology Administration of Argentina.

Data between parentheses correspond to $95 \%$ confidence interval limits. 
and connective tissue diseases $(17 \%)$, and endocrine, nutritional, and metabolic disorders $(11 \%)$ (Figure 1). Most usually, studied tumors included breast cancer $(\mathrm{N}=28)$, which accounted for $21 \%$ of neoplasms $(\mathrm{N}=123)$, followed by lung cancer $(\mathrm{N}=23)$, which accounted for $17 \%$ of neoplasms in this group. Among connective tissue diseases, the most common condition was rheumatoid arthritis $(\mathrm{N}=59)$ and among endocrine, nutritional, and metabolic disorders, it was diabetes $(\mathrm{N}=50)$.

Children. The most frequently studied diseases were respiratory diseases $(\mathrm{N}=10,16 \%)$, among which asthma was the most common $(\mathrm{N}=$ $8,13 \%)$. These were followed by musculoskeletal and connective tissue diseases $(\mathrm{N}=10,16 \%)$, among which juvenile idiopathic arthritis (JIA) $(\mathrm{N}=7,11 \%)$ was more common (Figure 2 ).

\section{RELATIONSHIP BETWEEN TRIALS IN CHILDREN AND INFANT AND CHILD MORTALITY}

Common causes of infant and child mortality in Argentina:
Between 0 to 4 years old: perinatal conditions, congenital malformations, accidents, pneumonia/ influenza, and pneumonitis due to solids and liquids. Between 5 and 14 years old: accidents, malignant tumors, congenital malformations, suicide. Between 15 and 24 years: accidents, suicide, assaults.

No correlation was observed between the most frequently studied diseases in children and the leading causes of infant and child mortality.

\section{DISCUSSION}

The study titled "The Globalization of Pediatric Clinical Trials," published in 2012 by the American Academy of Pediatrics, ${ }^{6}$ analyzed the characteristics of pediatric clinical trials approved between 2007 and 2010 and compared them to a previous period. Among analyzed outcome measures, the following are consistent with our study results: 1) phase III predominated; 2) placebo was used in $38 \%$ of trials, similar to what has been observed in this study $(31 \%) ; 3)$ trials conducted in developing countries focused most of all on asthma, consistent with this study.

TABLE 4. Association between age range and the use of placebo in clinical trials approved by the ANMAT* between 2011 and 2014

\begin{tabular}{lccc}
\hline Age range & With placebo N (\%) & Without placebo N (\%) & Total N (\%) \\
\hline Adults & $273(49 \%)$ & $279(51 \%)$ & $552(100 \%)$ \\
Children & $19(31 \%)$ & $43(69 \%)$ & $62(100 \%)$ \\
\hline
\end{tabular}

$\chi^{2}$ test with Yates $>$ correction $=7.172 ; p=0.0074$.

${ }^{*}$ National Drug, Food and Technology Administration of Argentina.

\section{Figure 1. Diseases studied in adults (classified by disease group) ${ }^{*}$}

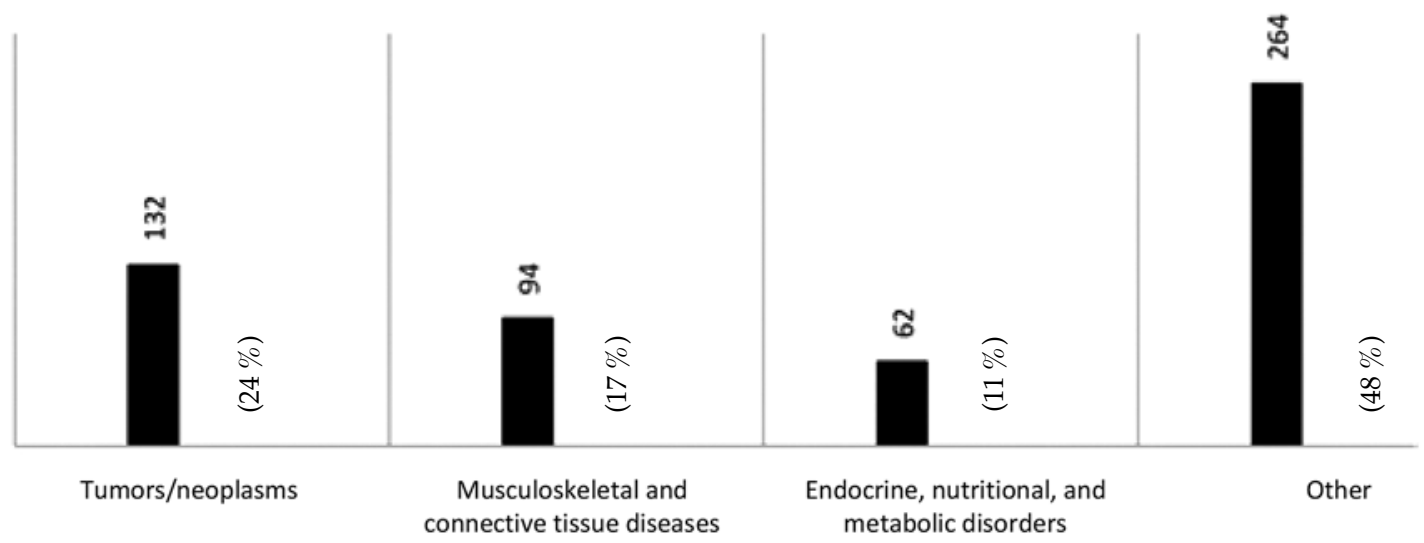

* International Classification of Diseases, $10^{\text {th }}$ Revision (ICD-10). 2008. WHO. ${ }^{3}$

Tumors / neoplasms, musculoskeletal and connective tissue diseases, and endocrine, nutritional, and metabolic disorders corresponded to the three categories representative of more than $50 \%$ of diseases studied in adult trials. 
A difference worth noting is that the abovementioned study analyzed only pediatric trials and did not compare them to those in the adult population.

This study confirms that more trials are conducted on adults than on children $(90 \%$ versus $10 \%)$. The lower number of pediatric trials may be related to the fact that drug research in children poses challenges and difficulties in terms of:

- Ethical aspects. Children are a vulnerable population so their participation as research subjects is a risk for an unequal distribution of burdens and benefits. ${ }^{7,8}$ Vulnerability is a critical characteristic of children, whose autonomy is relatively or absolutely restricted because they cannot protect their interests and integrity. ${ }^{9}$ As a result, children are more susceptible to damage or abuse and the risks may outweigh the benefits because the studied molecules are not completely known yet. This is why they require special protection, but this should not mean denying them the right to participate in clinical research because it would paradoxically make children more vulnerable as they would be exposed to treatments with drugs that had not been tested in them.

- Methodological aspects. The following should be considered when designing these studies:

- the number of patients is smaller, ${ }^{10}$
- initial dosage, safety, and tolerability data are mostly obtained in adults; outcome measures should be adjusted to pediatrics; it is necessary to assess the characteristics typical of this population, including physical growth and development and the development of absorption, distribution, metabolism, and excretion mechanisms; ${ }^{11}$

- long-term studies are required; ${ }^{12}$

- the use of placebo should be justified and restricted; ${ }^{12}$

- techniques involved should be as minimally invasive as possible, ${ }^{12}$

- it is necessary to minimize and justify blood volumes to be collected; ${ }^{12}$

- it should be noted that pediatrics covers different age ranges, each with their own characteristics, and in a long-term study, patients may shift from one group to another. $^{12}$

- Aspects related to human resources and infrastructure. The staff involved should be experienced in drug clinical research and in dealing with pediatric patients. In addition, research sites require their own infrastructure specially designed for pediatrics to prevent risks for participants.

- Sociocultural aspects. It is necessary to inform the society (including health care providers)

FIGURE 2. Diseases studied in children (classified by disease group)*

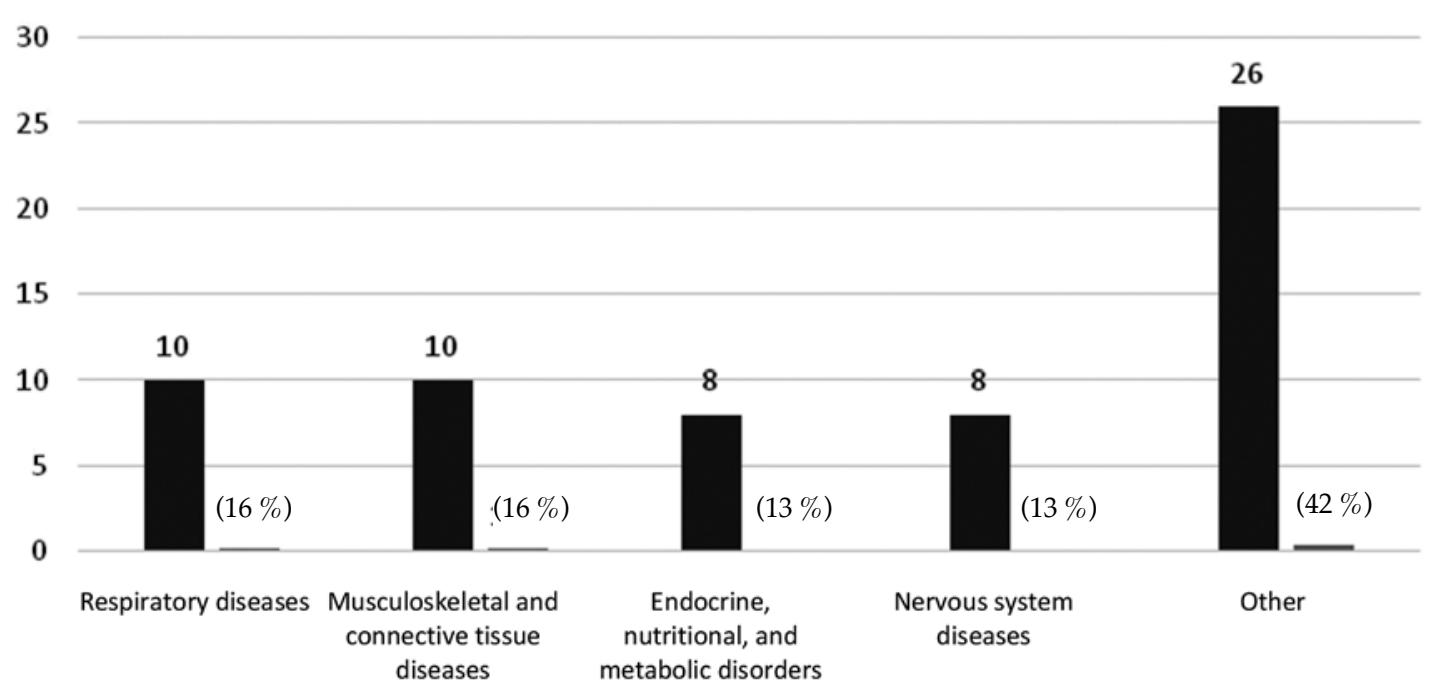

* International Classification of Diseases, $10^{\text {th }}$ Revision (ICD-10). 2008. WHO. ${ }^{3}$

Respiratory diseases, musculoskeletal and connective tissue diseases, endocrine, nutritional, and metabolic disorders, and nervous system diseases corresponded to more than $50 \%$ of disease categories studied in pediatric trials. 
on the drug development process in children and to highlight that participants are not subjected to an "experiment" or the object of exploitation.

In spite of these characteristics, it is worth noting that the number of pediatric clinical trials increased $100 \%$ between 2011 and 2014. This is in line with the prevailing need to have drugs that have been scientifically assessed in children and with the emergence of international regulations that promote this activity.

In relation to study phases, phase III predominated in both adults $(77 \%)$ and children $(69 \%)$. The number and proportion of early phase studies was low in both populations, not only in children, as initially proposed in this study. A possible reason might be that, in Argentina, during the study period, there was no regulation in place regarding phase I studies. In 2017, Provision $4009 / 17^{13}$ on requirements for health care sites conducting phase I studies and Provision $4008 / 17^{14}$ on requirements for clinical trials, including phase I studies, were passed. This may promote early phase research in our country.

In relation to placebo, results have shown a greater association between placebo use and adult age, which is consistent with international recommendations, ${ }_{1}^{15}$ which established that more restrictions should be applied to placebo use in children than in adults. In relation to blinding, the proportion of blind studies was higher than open-label studies in both populations, which is consistent with the existing recommendations that state that, like in the case of adults, pediatric trials should implement every measure possible to prevent bias. ${ }^{12}$

In relation to the most commonly studied diseases, no coincidence was observed when comparing adult and pediatric clinical trials. In the adult population, neoplasms predominated, mostly breast and lung cancer, in correlation with the numbers published by the National Ministry of Health of Argentina, ${ }^{4}$ which showed that malignant tumors were the leading cause of mortality in individuals aged 35-74 years.

In pediatrics, clinical trials focused more on respiratory diseases (with asthma as the most studied disease in this group) and musculoskeletal and connective tissue diseases, especially JIA.

The most commonly studied diseases in clinical trials done in children did not match the leading causes of infant and child mortality in Argentina. ${ }^{4}$ These findings may be explained by the fact that the main objective of clinical drug research is to develop new knowledge on molecules for clinical use, applicable not only for mortal diseases but in any health care situation requiring pharmacotherapeutic interventions. It would be interesting to have a clinical pharmacology branch to assess drugs aimed at reducing drug-related mortality in infants and children.

In addition, it should be noted that among the most studied diseases, asthma is the most common chronic respiratory disease and the leading cause of chronic morbidity in children, ${ }^{16}$ and that JIA is a pediatric disease that requires an aggressive initial treatment. ${ }^{17}$ These considerations help us to infer that, between 2011 and 2014, in Argentina, pediatric clinical trials were approved to study diseases that represented the health needs of this group, either because they are highly prevalent and/or because they occur in the pediatric population and require starting treatment at an early age. This is respectful of international ethical guidelines in the vulnerable population establishing that the purpose of research should aim at gathering relevant knowledge on this group's health needs. ${ }^{7}$

\section{CONCLUSIONS}

1) More studies were conducted in adults than in children; 2) phase III studies predominated in both populations; 3 ) significant differences were observed between adult and children in terms of study design, placebo use, and blinding; 4) studied diseases differed between both populations; 5) pediatric clinical trials approved during the study period did not correlate with the leading causes of infant and child mortality in Argentina.

\section{REFERENCES}

1. Saavedra I, Quiñones L, Saavedra M, et al. Farmacocinética de medicamentos de uso pediátrico, visión actual. Rev Chil Pediatr. 2008; 79(3):249-58.

2. Administración Nacional de Medicamentos, Alimentos y Tecnología Médica. Disposición 6677/10. Buenos Aires: Ministerio de Salud; 2010. [Accessed on: July 12 ${ }^{\text {th }}, 2018$ ]. Available at: http: / /www.anmat.gov.ar/webanmat/ Legislacion/Medicamentos/Dispo_6677-10.pdf.

3. Organización Mundial de la Salud. Clasificación Internacional de Enfermedades. 10.ma rev. [Accessed on: July $12^{\text {th }}$, 2018]. Available at: http: / / www.sssalud.gob.ar / hospitales/archivos/cie_10_revi.pdf.

4. Ministerio de Salud de la Nación Argentina - Secretaría de Políticas, Regulación e Institutos Dirección de Estadísticas e Información de Salud. Estadísticas vitales-Información Básica. Argentina-Año 2015. Buenos Aires: DEIS/MSAL, 2016;5(59). [Accessed on: July 12 ${ }^{\text {th }}, 2018$ ]. Available 
at: http: / / www.deis.msal.gov.ar/index.php/serie-5estadisticas-vitales/.

5. Instituto de Desenvolvimento Sustentável Mamirauá Programa Estadístico Biostat 5.3. [Accessed on: July 12 ${ }^{\text {th }}$, 2018]. Available at: https://www.mamiraua.org.br/ptbr/downloads / programas/bioestat-versao-53/.

6. Dunne J, Murphy D, Rodríguez W. The Globalization of Pediatric Clinical Trials. Pediatrics. 2012; 130(6):e1583-91.

7. Consejo de Organizaciones Internacionales de las Ciencias Médicas (CIOMS). Pautas éticas internacionales para la investigación biomédica en seres humanos. Ginebra: CIOMS; 2002. [Accessed on: July 12 ${ }^{\text {th }}, 2018$ ]. Available at:http: / / www1.paho.org/Spanish/BIO/CIOMS.pdf.

8. Asociación Médica Mundial. Declaración de Helsinki de la AMM - Principios éticos para las investigaciones médicas en seres humanos. 64. ${ }^{a}$ Asamblea General, Fortaleza, Brasil, 2013. [Accessed on: July 12 ${ }^{\text {th }}, 2018$ ]. Available at: https: / / www.wma.net/es/policies-post/declaracion-de-helsinkide-la-amm-principios-eticos-para-las-investigacionesmedicas-en-seres-humanos/.

9. Macklin R. Bioethics, vulnerability, and protection. Bioethics. 2003;17(5-6):472-86.

10. European Medicines Agency. Committee for Medicinal Products for Human Use Guideline Oon Clinical Trials in Small Populations. Londres: EMA; 2006. [Accessed on: July $\left.12^{\text {th }}, 2018\right]$. Available at: http://www.ema. europa.eu/docs/en_GB/document_library/Scientific_ guideline/2009/09/WC500003615.pdf.

11. Kearns GL, Abdel-Rahman SM, Alander SW, et al. Developmental pharmacology--drug disposition, action, and therapy in infants and children. $N$ Engl J Med. 2003; 349(12):1157-67.

12. ICH Expert Working Group. Clinical investigation of medicinal products in the pediatric population (E11). ICH Harmonised Tripartite Guideline. 2000. [Accessed on: July $\left.12^{\text {th }}, 2018\right]$. Available at: http:/ / www.ich.org/fileadmin/ Public_Web_Site/ICH_Products/Guidelines/ Efficacy/ E11 /Step4/E11_Guideline.pdf.

13. Administración Nacional de Medicamentos, Alimentos y Tecnología Médica. Disposición 4009/17. Buenos Aires: Ministerio de Salud; 2017. [Accessed on: July 12 $2^{\text {th }}, 2018$ ]. Available at: http:/ / www.anmat.gov.ar/boletin_anmat / BO/Disposicion_4009-2017.pdf.

14. Administración Nacional de Medicamentos, Alimentos y Tecnología Médica. Disposición 4008/17. Buenos Aires: Ministerio de Salud; 2017. [Accessed on: July 12 ${ }^{\text {th }}$, 2018]. Available at: http:/ / www.anmat.gov.ar/boletin_anmat/ Abril_2017/Dispo_4008-17.pdf.

15. European Medicines Agency. Committee for Medicinal Products for Human Use. Ethical Considerations for Clinical Trials on Medicinal Products Conducted with the Paediatric Population. 2008. [Accessed on: July 12 $2^{\text {th }}, 2018$ ]. Available at: http: / / ec.europa.eu/health/ / sites / health/files / files / eudralex/vol-10/ethical_considerations_en.pdf.

16. Comité Nacional de Neumonología, Comité Nacional de Alergia, Comité Nacional de Medicina Interna, Comité Nacional de Familia y Salud Mental. Guía de diagnóstico y tratamiento: asma bronquial en niños $\geq 6$ años. Actualización 2016. Resumen ejecutivo. Arch Argent Pediatr. 2016; 114(6):595-6.

17. Cuttica R, Cervetto V, Pringe A, et al. Guías de práctica clínica en artritis idiopática juvenil. Sociedad Argentina de Pediatría-Sociedad Argentina de Reumatología; 2011. [Accessed on: July 12 $\left.{ }^{\text {th }}, 2018\right]$. Available at: http:/ / www. reumatologia.org.ar/docs/guias_practica_clinica_artritis_ idiopatica_juven il_2011.pdf. 